\section{Treatment with different fining agents of white musts from spoiled wine grapes}

\author{
Eric Meistermann, ${ }^{1}$ Michel Pinsun ${ }^{2}$ \\ ${ }^{1}$ Pôle Alsace, Institut Français de la \\ Vigne et du Vin, Colmar; ${ }^{2}$ Chambre \\ d'Agriculture d'Alsace, Colmar, France
}

\begin{abstract}
Fining agents have evolved significantly over the last twenty years. The need for winemakers to have objective references about the new products has prompted this study. The experiment consists in comparing the new fining products (charcoal, pea proteins, derivatives of chitin and composite products generally mixing PVPP + various proteins + bentonite) with reference products such as casein and PVPP and with non-treated controls. Fining agents were applied during clarification of 15 different musts obtained from wine grapes affected by different degrees and types of rot: fresh and dry Botrytis cinerea rot, powdery mildew and Botrytis contaminated with other fungi (Aspergillus, Penicillium, Basidiomycetes), giving the bunches offflavours that were earthy and resembled fresh mushrooms. This study highlights the importance of good clarification of musts. The quality of control wines, without any treatment, increases with the clarity of the must. In most experiments, clarification of the must around 50 Nephelometric Turbidity Units (NTU) can eliminate or reduce any organoleptic defects in wine without fining. Use of pectolytic enzymes may be necessary in order to reach this level of clarity. The new allergen-free fining agents have the same effectiveness as reference products such as casein and polyvinylpolypyrolidone (PVPP) Composite products are more efficient than pea protein alone and less than products including charcoal. However, the improvement of aromatic quality goes hand in hand with loss of body and persistence.
\end{abstract}

\section{Introduction}

Historical wine fining agents are all animal proteins (edible gelatin, isinglass, casein and potassium caseinates, egg albu$\mathrm{min})$. Use of inorganic fining and stabilisation agents is more recent: bentonite and kaolin in the 1950s, silicon dioxide allowed by the EU in 1979 (EEC n³37/79) and polyvinylpolypyrrolidone (PVPP) allowed in $1988\left(\right.$ EEC n $\left.^{\circ} 2253 / 88\right)$.

Several constraints (bovine spongiform encephalopathy in the 1990s and the requirement to include all ingredients with allergenic effect in the labelling in 2012) have led manufacturers of oenological products to develop new fining agents. Early research focussed on plant proteins ${ }^{1,2}$ and led to authorisation of wheat and pea proteins in 2005 (CE n $\left.{ }^{\circ} 2165 / 2005\right)$. Wheat gluten is considered a common allergen and thus is subject to labelling requirements. Research into allergy-friendly products concentrated on study of non-protein compounds. Derivatives of chitin are natural polysaccharides extracted from Aspergillus niger mycelium which have found widespread applications in oenology. ${ }^{3}$ They have been authorised by the EU since 2011 (CE $n^{\circ} 53 / 2011$ ). In order to favour compounds that are naturally present in wine, research focussed on yeast derivative products including yeast proteins. ${ }^{4}$ The European Union added the use of yeast protein extracts to its permitted oenological practices for the treatment of musts and wines (CE n $\left.{ }^{\circ} 144 / 2013\right)$ and also a potato glycoprotein called patatin $\left(\mathrm{CE} \mathrm{n}^{\circ} 1251 / 2013\right)$ which can diminish the content of phenolics in wine. ${ }^{5,6}$

Grapevine bunch rots can impact must and wine quality negatively by increasing susceptibility to oxidation and the risks of wine faults and organoleptic deficiencies. The treatment of these musts with casein, used alone or in combination with bentonite or PVPP, was usually recommended. ${ }^{7,8}$ Owing to the allergenic characteristics of casein, its use in wine processing will require a declaration on the label, so producers of oenological products have developed allergen-free alternatives to casein. Moreover, since 2005, treatment with charcoal for oenological use of must and new wine still in fermentation is allowed by the European Union (CE n'2165/2005). The offer of products intended to treat musts from spoiled grapes has increased significantly over the last ten years. Winemakers needed objective technical references about these new products.

The aim of this study is to assess the effectiveness of many allergen-free fining products as alternatives to casein for the treatment of musts from grapes affected by rots and to provide winemakers with objective references. The evaluation focussed on colour, phenolic content and sensory characteristics.
Correspondence: Eric Meistermann. Biopôle, 28 rue de Herrlisheim, 68000 Colmar, France. Tel.: +33(0)3.89.30.22.72.

E-mail: eric.meistermann@vignevin.com

Key words: white wine, fungal rot, fining, wine quality.

Contributions: the authors contributed equally.

Conflict of interest: this work was partially funded by FranceAgriMer, French Agency for Agriculture and Food Products.

Fundings: this work was partially funded by FranceAgriMer, French Agency for Agriculture and Food Products.

Conference presentation: part of this paper was presented at the Fourth Edition of the International Conference Series on Wine Active Compounds (WAC2017) - 29, 30, 31 March 2017, Beaune, France.

Received for publication: 30 June 2017.

Revision received: 31 August 2017.

Accepted for publication: 1 September 2017.

This work is licensed under a Creative Commons Attribution NonCommercial 4.0 License (CC BY-NC 4.0).

CC Copyright E. Meistermann and M. Pinsun, 2017 Licensee PAGEPress, Italy

Wine Studies 2017; 6:6871

doi:10.4081/ws.2017.6871

\section{Materials and Methods}

\section{Characteristics of the musts}

Experiments are set up after crushing non-clarified musts, either from mechanical harvesting and collected under the winepress in industrial conditions, or obtained in experimental winery from grapes selected in the vineyard. Fifteen trials were conducted during vintages 2011 to 2013. The sanitary state of the grapes was visually evaluated by determination of the botrytis severity (percentage of bunch area infected), the kind of botrytis rot (fresh or dry), the presence of other diseases (powdery mildew) and the presence of various fungi (Aspergillus, Penicillium, Basidiomycetes). The presence of off-flavours on bunches was also noted. These trials can be grouped in four categories according to the type of rot: i) Botrytis low: percentage of rot lower than $30 \%$, fresh rot without other contamination. Five trials were made with the Pinot Gris grape variety and one with Riesling; ii) Botrytis high: more than $30 \%$ rot, fresh or 
more dry rot. Two trials were made with the Riesling grape variety, one with Sylvaner and one with Pinot Blanc. iii) Powdery mildew: bunches with more than $50 \%$ of bunch area infected. Three trials were made with this kind of disease, one with the Chardonnay grape variety, one with Pinot Blanc and one with Pinot Gris. iv) Other rots: Botrytis contaminated with moulds, bunches with off-flavours that were earthy and recalled fresh mushrooms. These trials, on the Pinot Gris grape variety, were not representative of a normal harvest.

\section{Experiments in the laboratory on a semi-industrial scale}

Musts collected after crushing were added with sulphite $(5-8 \mathrm{~g} / \mathrm{hl})$ and a preparation of pectolytic enzymes (with the exception of non-treated controls). Fining agents were added in must as recommended by the manufacturers. Musts were set to decantation at $11^{\circ} \mathrm{C}$ for a period of $18-20$ hours. After racking, turbidity of the treated variants were adjusted to the same level by addition of fine deposit. Musts were put into fermentation with the addition of active dried yeasts. After alcoholic fermentation, a second racking was made and also an addition of sulphites $(7-8 \mathrm{~g} / \mathrm{hl})$. On the laboratory scale, experiments were conducted in $1000 \mathrm{~mL}$ flasks, and wines were conserved in $750 \mathrm{~mL}$ bottles until they underwent sensory evaluation. On the experimental winery scale, experiments were conducted in 20
L glass containers and wines were stabilised and filtered on membrane cartridges to 3 $\mu \mathrm{m}$ and $0.65 \mu \mathrm{m}$ before bottling and closure with screw caps.

\section{Oenological products and treat- ments compared}

All experiments, both on the laboratory and the experimental winery scale, included non-treated controls with two or three turbidity levels, in general 200, 100 and 50 NTU (Nephelometric Turbidity Unit); one variant was only treated with pectolytic enzymes (Enzym Must ${ }^{\circledR}$, Oenofrance), one with casein (Siha Kasein ${ }^{\circledR}$, Bergerow SIHA) and one other with PVPP (PolyEx ${ }^{\circledR}$, Oenofrance). The following allergen-free fining agents were studied (all registered products): i) Oenological charcoal alone: GOTA (Oenofrance), Geosorb (Laffort), Flavoclean (IOC); ii) Oenological charcoal in association: GOTA + Formule 1-CF (Oenofrance), Polypresse AF (Martin Vialatte); iii) Pea proteins: Prov Green Pure Must (Martin Vialatte), LittoFresh Origine (La Littorale), Greenfine Must (Lamothe Abiet), Inofine V (IOC); iv) Derivatives of chitin: Qi'No[Ox] (IOC); v) Composite products, usually composed of PVPP, proteins and bentonite: Mostogel (Erbslöh); Colorprotect V and Viniprotect (IOC); LittoPur and LittoFresh Most (La Littorale); Polymust AF (Laffort); Polymix Natur (Lamothe Abiet); Polygreen (Martin Vialatte); Formule 1-CF and Altocase
(Oenofrance); Oenocer, Oenocil and Vegane Colle (Oenolia Conseil AEB).

Experiments included between 20 and 30 treatments on the laboratory scale and between 12 and 16 treatments on the experimental winery scale.

\section{Analysis of conventional oenological parameters and colour}

Turbidity was measured using a Hach Ratio $\mathrm{x} / \mathrm{R}$ turbidimeter. Sugar content, $\mathrm{pH}$, titratable acidity, free and total sulphur dioxide were measured according to the standards of the Organisation Internationale de la Vigne et du Vin. ${ }^{9}$ Colour was determined by measuring absorbance at $420 \mathrm{~nm}$ (10 mm cell) using a Shimadzu UVmini1240 spectrophotometer. The phenolic content was determined by a spectrophotometric method and expressed as a total phenolic index (TPI $=\mathrm{A}_{280 \mathrm{~nm}} \times$ dilution factor). ${ }^{10}$

\section{Sensory evaluation}

Sensory evaluation was performed at three stages during the winemaking. After must clarification and after alcoholic fermentation, all musts and wines were blindtasted by three consultant oenologists (males aged 56, 51 and 36 years) and a global quality score was attributed to each variant with a detailed commentary.

Bottled wines from the experimental winery scale were presented three times to a panel of 12-15 trained winemakers, 2-4 months after bottling, and one and two

Table 1. Colour and total phenols of fined and unfined musts after racking and white wines after bottling (mean \pm SD).

Musts after racking
Fining treatment $\quad$ n. Colour $\triangle D 0420 \triangle$ Tlotal Phenol Index after bottling
n. Colour $\triangle D 0420 \quad \Delta$ Total Phenol Index

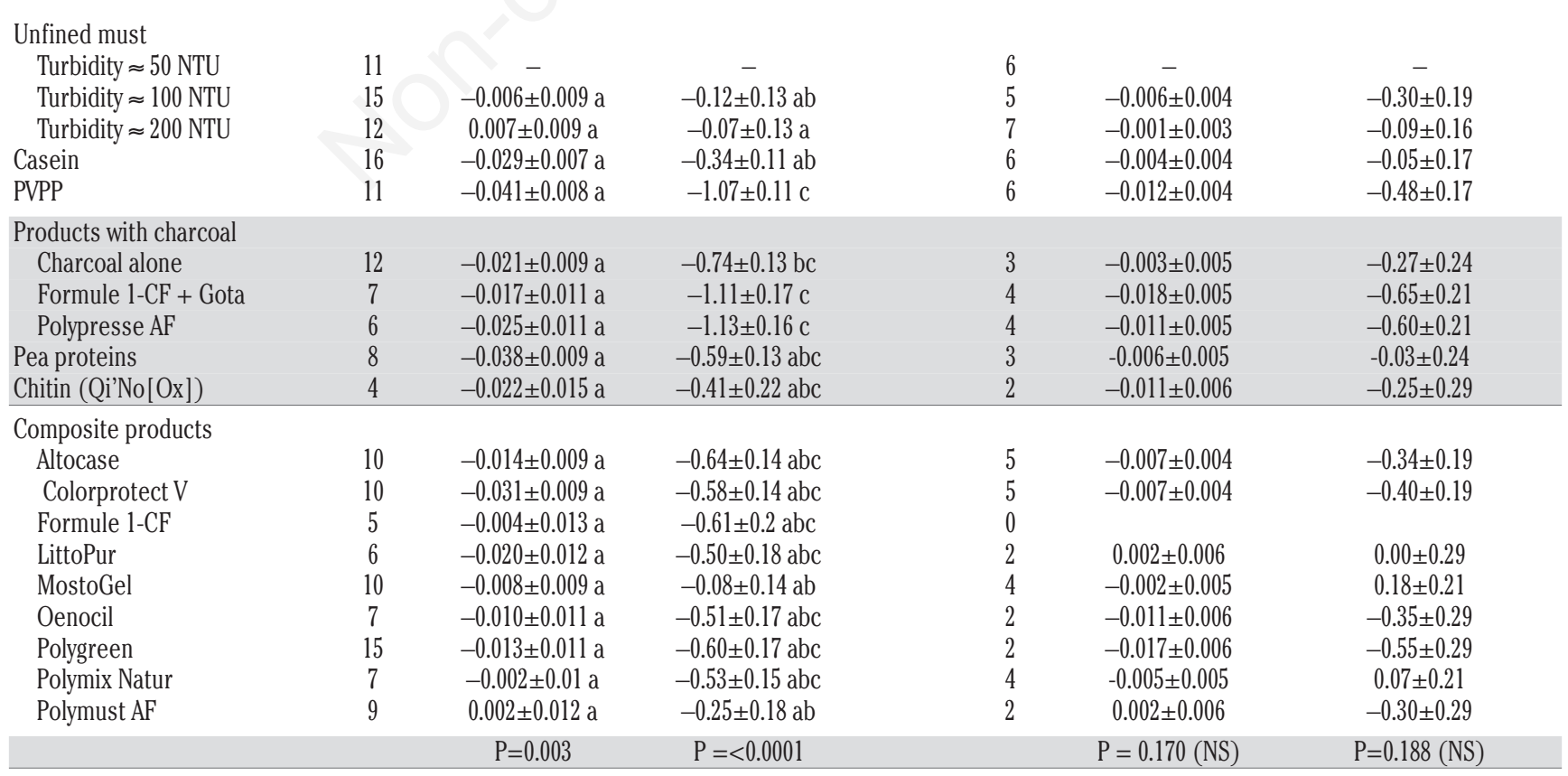

$\mathrm{n}=$ number of samples analysed 
years later. Samples were presented to the panel in tasting glasses in a randomised order. Eleven attributes were selected: visual (colour intensity), aroma (intensity and quality) and taste (smoothness, warmth, acidity, bitterness, body, balance, persistence) and a global quality rating. The attributes were quantified using a five-point intensity scale.

\section{Statistical analysis}

The data are presented as mean \pm standard deviation. They were statistically tested by analysis of variance (ANOVA) using XLSTAT Base 19.4 software (Addinsoft, France, 2017). Fisher's least significant difference test (LSD, 5\% level) was applied to determine significant differences between the treatments. The model was statistically significant when $\mathrm{P}$ values were less than 0.05 .

\section{Results and Discussion}

\section{Effect of fining agents on conven- tional oenological parameters, colour and total phenol index}

Sugar content, total acidity and $\mathrm{pH}$ values did not differ much between treated and untreated musts. Turbidity of musts from each trial was adjusted at the same level by the addition of fine deposit. It ranged between 50 and 100 NTU. Grape rot impacts colour and phenol compounds of musts and wines. ${ }^{11}$ To overcome these effects, results are presented in terms of difference as compared to unfined must (50 NTU) from each trial (Table 1). Means within a column followed by the same letter are not significantly different (LSD, 5\%).
Most fining agents reduce colour and the total phenolic index. Effect on the colour of musts is greater with pea proteins, PVPP, casein and products containing charcoal than with composite products. These differences are minimised by alcoholic fermentation and the colour of bottled wines

Table 2. Sensory analysis of fined and unfined musts after racking and white wines after fermentation $($ mean $\pm S D)$. Global quality score out of 5 points.

\begin{tabular}{|c|c|c|c|}
\hline Fining treatment & n. & $\begin{array}{l}\text { Musts after racking } \\
\text { (score } / 5)\end{array}$ & $\begin{array}{l}\text { Wines after fermentation } \\
\qquad(\text { score } / 5)\end{array}$ \\
\hline \multicolumn{4}{|l|}{ Unfined must } \\
\hline Turbidity $\approx 50$ NTU & 17 & $2.7 \pm 0.3 \mathrm{~b}$ & $3.5 \pm 0.3 \mathrm{c}$ \\
\hline Turbidity $\approx 100$ NTU & 15 & $2.2 \pm 0.3 \mathrm{ab}$ & $2.0 \pm 0.3 \mathrm{abc}$ \\
\hline Turbidity $\approx 200$ NTU & 17 & $1.1 \pm 0.3 \mathrm{a}$ & $1.5 \pm 0.3 \mathrm{a}$ \\
\hline Casein & 19 & $3.1 \pm 0.2 \mathrm{~b}$ & $2.6 \pm 0.2 \mathrm{abc}$ \\
\hline PVPP & 17 & $2.8 \pm 0.3 \mathrm{~b}$ & $2.5 \pm 0.3 \mathrm{abc}$ \\
\hline \multicolumn{4}{|l|}{ Products with charcoal } \\
\hline Charcoal alone & 15 & $3.1 \pm 0.3 \mathrm{~b}$ & $2.9 \pm 0.3 \mathrm{abc}$ \\
\hline Formule 1-CF + Gota & 14 & $2.8 \pm 0.3 \mathrm{~b}$ & $2.9 \pm 0.3 \mathrm{abc}$ \\
\hline Polypresse AF & 8 & $3.3 \pm 0.3 \mathrm{~b}$ & $2.4 \pm 0.4 \mathrm{abc}$ \\
\hline Pea proteins & 17 & $2.3 \pm 0.3 \mathrm{ab}$ & $2.4 \pm 0.3 \mathrm{abc}$ \\
\hline Chitin (Qi’No[Ox]) & 10 & $3.3 \pm 0.4 \mathrm{~b}$ & $2.7 \pm 0.3 \mathrm{abc}$ \\
\hline \multicolumn{4}{|l|}{ Composite products } \\
\hline Altocase & 14 & $3.2 \pm 0.3 \mathrm{~b}$ & $3.2 \pm 0.3 b c$ \\
\hline Colorprotect V & 11 & $3.0 \pm 0.3 \mathrm{~b}$ & $3.0 \pm 0.3 \mathrm{bc}$ \\
\hline Formule 1-CF & 6 & $3.0 \pm 0.4 \mathrm{~b}$ & $3.0 \pm 0.4 \mathrm{abc}$ \\
\hline LittoPur & 7 & $2.9 \pm 0.4 \mathrm{~b}$ & $2.4 \pm 0.4 \mathrm{abc}$ \\
\hline MostoGel & 10 & $2.7 \pm 0.3 b$ & $2.7 \pm 0.3 \mathrm{abc}$ \\
\hline Oenocil & 8 & $1.9 \pm 0.3 \mathrm{ab}$ & $2.6 \pm 0.4 \mathrm{abc}$ \\
\hline Polygreen & 14 & $2.6 \pm 0.3 \mathrm{~b}$ & $2.5 \pm 0.3 \mathrm{abc}$ \\
\hline Polymix Natur & 10 & $2.9 \pm 0.3 \mathrm{~b}$ & $2.5 \pm 0.3 \mathrm{abc}$ \\
\hline \multirow[t]{2}{*}{ Polymust AF } & 7 & $2.7 \pm 0.4 \mathrm{~b}$ & $3.0 \pm 0.4 \mathrm{abc}$ \\
\hline & & $\mathrm{P}=<0.0001$ & $\mathrm{P}=0.001$ \\
\hline
\end{tabular}

$\mathrm{n}=$ number of samples analysed

Table 3. Global sensory quality (score/5) of fined and unfined white wines after bottling (mean \pm SD).

\begin{tabular}{|c|c|c|c|c|c|c|}
\hline Fining treatment & $\begin{array}{c}\text { Botrytis low } \\
\text { (11.F3) }\end{array}$ & $\begin{array}{c}\text { Botrytis low } \\
\text { (11.F4) }\end{array}$ & $\begin{array}{c}\text { Botrytis high } \\
(12 . \mathrm{F} 4)\end{array}$ & $\begin{array}{c}\text { Botrytis high } \\
\text { (13.F5) }\end{array}$ & $\begin{array}{c}\text { Powdery mildew } \\
\text { (12.F2) }\end{array}$ & $\begin{array}{l}\text { Other rots } \\
\text { (13.F4) }\end{array}$ \\
\hline $\begin{array}{l}\text { Unfined must } \\
\text { Turbidity } \approx 50 \text { NTU } \\
\text { Turbidity } \approx 100 \text { NTU } \\
\text { Turbidity } \approx 200 \text { NTU } \\
\text { Casein } \\
\text { PVPP }\end{array}$ & $\begin{array}{c}3.1 \pm 0.2 \mathrm{c} \\
2.9 \pm 0.2 \mathrm{abc} \\
2.5 \pm 0.2 \mathrm{ab} \\
2.9 \pm 0.3 \mathrm{abc} \\
2.8 \pm 0.2 \mathrm{abc}\end{array}$ & $\begin{array}{c}3.4 \pm 0.3 \mathrm{c} \\
2.6 \pm 0.3 \mathrm{ab} \\
2.2 \pm 0.3 \mathrm{a} \\
2.8 \pm 0.2 \mathrm{abc} \\
2.9 \pm 0.3 \mathrm{bc}\end{array}$ & $\begin{array}{c}3.1 \pm 0.2 \mathrm{c} \\
2.7 \pm 0.2 \mathrm{c} \\
2.1 \pm 0.2 \mathrm{ab} \\
2.1 \pm 0.3 \mathrm{ab} \\
2.8 \pm 0.3 \mathrm{c}\end{array}$ & $\begin{array}{c}3.0 \pm 0.3 \mathrm{c} \\
2.8 \pm 0.3 \mathrm{bc} \\
1.8 \pm 0.2 \mathrm{a} \\
2.8 \pm 0.4 \mathrm{bc} \\
2.7 \pm 0.4 \mathrm{bc}\end{array}$ & $\begin{array}{c}3 \pm 0.1 \mathrm{c} \\
- \\
2.3 \pm 0.2 \mathrm{a} \\
2.5 \pm 0.2 \mathrm{abc} \\
2.6 \pm 0.2 \mathrm{abc}\end{array}$ & $\begin{array}{c}1.8 \pm 0.2 \mathrm{abc} \\
2.0 \pm 0.2 \mathrm{abc} \\
1.7 \pm 0.1 \mathrm{a} \\
2.2 \pm 0.2 \mathrm{bc} \\
2.3 \pm 0.2 \mathrm{~cd}\end{array}$ \\
\hline $\begin{array}{l}\text { Products with charcoal } \\
\text { Charcoal alone } \\
\text { Formule 1-CF+Gota } \\
\text { Polypresse AF } \\
\text { Pea proteins (Greenfine) } \\
\text { Chitin (Qi'No[Ox]) }\end{array}$ & $\begin{array}{l}2.5 \pm 0.2 \mathrm{ab} \\
2.7 \pm 0.2 \mathrm{abc}\end{array}$ & $\begin{array}{l}2.9 \pm 0.2 \mathrm{bc} \\
2.5 \pm 0.2 \mathrm{ab}\end{array}$ & $\begin{array}{l}1.9 \pm 0.2 \mathrm{a} \\
2.6 \pm 0.2 \mathrm{bc}\end{array}$ & $\begin{array}{l}2.5 \pm 0.3 b c \\
2.7 \pm 0.4 b c \\
2.5 \pm 0.2 b c\end{array}$ & $\begin{array}{l}2.6 \pm 0.2 \mathrm{abc} \\
2.6 \pm 0.2 \mathrm{ab}\end{array}$ & $\begin{array}{c}2.3 \pm 0.2 \mathrm{~cd} \\
2.7 \pm 0.2 \mathrm{~d} \\
2.1 \pm 0.2 \mathrm{abc} \\
2.2 \pm 0.2 \mathrm{bc}\end{array}$ \\
\hline $\begin{array}{l}\text { Composite products } \\
\text { Altocase } \\
\text { Colorprotect V } \\
\text { LittoPur } \\
\text { MostoGel } \\
\text { Oenocil } \\
\text { Polygreen } \\
\text { Polymix Natur } \\
\text { Polymust AF } \\
\text { LittoFresh Most } \\
\text { Oenocer }\end{array}$ & $\begin{array}{c}2.7 \pm 0.2 \mathrm{abc} \\
2.8 \pm 0.2 \mathrm{abc} \\
\\
2.8 \pm 0.2 \mathrm{abc} \\
2.4 \pm 0.2 \mathrm{a} \\
3 \pm 0.2 \mathrm{bc}\end{array}$ & $\begin{array}{c}2.7 \pm 0.3 \mathrm{abc} \\
2.6 \pm 0.3 \mathrm{ab} \\
2.9 \pm 0.3 \mathrm{bc} \\
2.9 \pm 0.3 \mathrm{bc} \\
2.9 \pm 0.2 \mathrm{bc}\end{array}$ & $\begin{array}{c}2.6 \pm 0.2 \mathrm{bc} \\
2.8 \pm 0.3 \mathrm{c} \\
2.9 \pm 0.2 \mathrm{c} \\
2.8 \pm 0.2 \mathrm{c}\end{array}$ & $\begin{array}{l}2.7 \pm 0.4 \mathrm{bc} \\
2.5 \pm 0.2 \mathrm{bc} \\
2.2 \pm 0.3 \mathrm{ab}\end{array}$ & $\begin{array}{l}2.8 \pm 0.2 \mathrm{bc} \\
2.6 \pm 0.1 \mathrm{abc} \\
2.7 \pm 0.2 \mathrm{abc} \\
2.5 \pm 0.2 \mathrm{abc}\end{array}$ & $\begin{array}{l}2.3 \pm 0.3 \mathrm{~cd} \\
2.1 \pm 0.2 \mathrm{abc}\end{array}$ \\
\hline & $\mathrm{P}=<0.0001$ & $\mathrm{P}=<0.0001$ & $\mathrm{P}=<0.0001$ & $\mathrm{P}=<0.0001$ & $\mathrm{P}=<0.0001$ & $\mathrm{P}=<0.0001$ \\
\hline
\end{tabular}


shows fewer differences. Anneraud et al. ${ }^{12}$ also showed that the efficiency of pea proteins is comparable to casein, but according to Cosme et al..$^{13}$ they are less effective in reducing the white wine browning potential. The reduction of phenolic compounds in musts is considerable after fining with PVPP, products containing charcoal and composite products which all contain PVPP. It is lower with casein and pea proteins. The reduction is still perceptible after bottling but differences are not significant.

\section{Effects of the fining agents on senso- ry evaluation}

Results of the sensory evaluation of musts and after fermentation (Table 2) at first highlight the importance of must clarification on unfined wine quality. The clearest unfined control presents on average the best sensory quality for both musts and wines as opposed to less clarified musts. There is an obvious link between the turbidity of unfined musts and the global quality of wines after fermentation (Figure 1). Only in the case of off-flavours does clarification have no effect on wine quality (trial 13.F4).
All fining products improve the organoleptic quality of must with the excep-

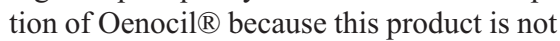
neutral in terms of aroma. It develops a rancid odour that is perceptible in must but much less so in wine. After alcoholic fermentation, the clearest unfined control presented a better overall sensory quality than fined variants with turbidity that is higher after must clarification. The positive effect of fining is less pronounced on wine that on must. This may probably be explained by the fact that some molecules responsible for off-flavours in musts are degraded during alcoholic fermentation as is the case with 2Methylisoborneol. ${ }^{14}$ Sensory improvement after fining is lower with pea proteins then with other products for both musts and wines.

Wines from the experimental winery scale were presented to a trained panel of 12-15 winemakers. The results of the first sensory evaluation after bottling as a global sensory score are reported in Table 3.

The importance of good clarification of musts before fermentation is confirmed. Only in the case of off-flavours due to rots other than Botrytis is clarification incapable of improving the wine quality.

For the grape harvest with little Botrytis (category Botrytis low), the aromatic quality enhancement after fining is not enough to compensate for the loss of persistence in the mouth resulting in lower global wine quality. This effect is perceptible with charcoal products. The negative impact of the product Oenocil $\AA$ is clear in trial 11 .F3 but less pronounced in trial 11.F4. Even when the Botrytis rate is higher (category Botrytis high), the clearest unfined control was still preferred by the panel of tasters. The same results were observed in the case of grapes infected with powdery mildew. Moreover, during the aging process of bottled wines, differences between treatments tend to decrease. If grapes are affected with other rots and earthy or mushroomy off-flavours, all fining products, especially charcoal products, have a positive effect on the wine quality. However, pea proteins are of little interest for enhancing the aromatic quality of wines.

\section{Conclusions}

This study shows that in the case of wine grape rot without off-flavours such as earthy or mushroomy odours, meticulous clarification of must after crushing can enhance the wine quality and avoid the consequences of grape rot. Fining products are not necessary. The turbidity of must after clarification has to be around 50 NTU. Use of pectolytic enzymes may be required in order to achieve this degree of clarification. However, excessive trituration of bunches can render must clarification impossible.

The effectiveness of fining products to improve sensory quality is more evident when tasting musts after clarification than in wines after alcoholic fermentation, probably because some off-flavour molecules are broken down during fermentation. The need for treatment is less frequent than generally accepted.

New allergen-free fining products used during clarification of musts from spoiled wine grapes are at least as effective for improving wine quality as reference products such as casein and PVPP alone. The efficiency of composite products including PVPP, proteins and fining agents is better than that of pea proteins and lower than charcoal products. However, fining musts during clarification can enhance the quality of the wine after fermentation, yet this is always accompanied to a greater or lesser extent by a loss of persistence and mouthfeel. The impact of fining on global wine quality depends on the balance of these two
Figure 1. Relationship between turbidity (NTU) of unfined musts after racking and global sensory quality of wines after alcoholic fermentation for the different trials carried out with different types of wine grape rots: Botrytis low $(\boldsymbol{\Delta})$, Botrytis high $(\bullet)$, powdery mildew $(\bigcirc)$ and other rots $\left({ }^{*}\right)$. 
opposite effects.

\section{References}

1. Moutounet M. Intérêt de l'utilisation des protéines végétales pour le collage des moûts et des vins. Rev Franç Enol 2006;17:1-4.

2. Lefebvre S, Gerland C, Maury C, Gazzola M. Nouvelles colles végétales: origines, propriétés et performances. Rev Franç Enol 2000;84:28-32.

3. Bornet A, Teissedre P-L. Intérêt de l'utilisation de chitine, chitosane et de leurs dérivés en œnologie. J Int Sci Vigne Vin 2005;39:199-207.

4. Silvano A. Les produits dérivé de levure: quels produits? quels usages? Stage IFV de formation en oenologie; Colmar, 1 mars 2016.

5. Gambuti A, Rinaldi A, Moio L. Use of patatin, a protein extracted from potato, as alternative to animal proteins in fining of red wine. Eur Food Res Technol 2012;235:753-65.

6. Iturmendi N, Moine V, Rinaldi A, et al. Les protéines issues de pomme de terre: agent de collage des moûts des vins. Rev Franç CEnol 2016;279:2-7.

7. Tribaut-Sohier I, Valade M. Les traitements fermentaires des moûts issus de vendanges botrytisées. Vigneron Champenois 2000;121:30-41.

8. Weik B. Schönung mit Kasein und PVPP. Der Deutsche Weinbau 1994;4:17.

9. OIV. Recueil de méthodes internationales d'analyse des vins et des moûts. Paris: Edition Officielle; 2009.

10. Vivas N, Vivas de Gaulejac N, Nonier MF. Sur l'estimation des composés phénoliques des vins. Bull OIV 2003;8656:281-303.

11. Steel CC, Blackman JW, Schmidtke
LM. Grapevine bunch rots: impacts on wine composition, quality, and potential procedures for the removal of wine faults. J Agr Food Chem 2013;61:5189206.

12. Anneraud C, Cayla L. Collage des moûts et des vins. Utilisation des protéines végétales. Coût Fournit Viticult Enol 2015;13-6.

13. Cosme F, Capão I, Filipe-Ribeiro L, et al. Evaluating potential alternatives to potassium caseinate for white wine fining: effects on physicochemical and sensory characteristics. LWT-Food Sci Technol 2012;46:382-7.

14. Rousseaux S, Diguta CF, Radoï-Matei $F$, et al. Non-Botrytis grape-rotting fungi responsible for earthy and moldy off-flavors and mycotoxins. Food Microbiol 2014;38:104-21. 